\title{
The role of magnetic resonance imaging in refining the diagnosis of suspected fetal renal anomalies
}

\section{Sü̈pheli fetal renal anomali tanısını aydınlatmada manyetik rezonans görüntülemenin rolü}

\author{
Ibrahim Anwar Abdelazim ${ }^{1,3}$, Maha Mohamed Belaf,,3 \\ 'Department of Obstetrics and Gynecology, Ain Shams University Maternity Hospital, Faculty of Medicine, Ain Shams \\ University, Cairo, Eygpt \\ ${ }^{2}$ Department of Diagnostic Radiology, Mansoura University Hospital, Faculty of Medicine, Mansoura University, Cairo, Egypt \\ ${ }^{3}$ Al-Rashid Maternity Hospital, Salmyia, Kuwait
}

\section{Abstract}

Objective: This prospective study was designed to detect the role of magnetic resonance imaging (MRI) in refining the diagnosis of suspected fetal renal anomalies detected during screening sonography.

Material and Methods: 54 pregnant women, with suspected fetal renal anomalies detected during routine ultrasound screening, were rescanned by MRI to refine the diagnosis of the suspected renal anomalies. The pregnancy outcome was examined externally and by postnatal ultrasonography.

Results: Fifty-four cases of suspected renal anomalies detected during screening sonography of 8400 pregnant women $(0.6 \%)$, were rescanned by MRI in this study.

The MRI gave a similar diagnosis to postnatal ultrasound in 46 cases (16 cases of hydronephrosis, 14 cases of Polycystic Kidney Disease (PCKD), 9 cases of Multicystic Kidney Disease (MCKD), 2 cases of Renal Agensis (RA), 3 cases of single renal cyst and 2 cases of megacystis + hydroureter), while it gave a different diagnosis (false positive) in 6 cases ( 4 cases of hydronephrosis diagnosed by MRI confirmed to be PCKD by postnatal ultrasound, also, 1 case of MCKD diagnosed by MRI confirmed to be hydronephrosis by postnatal ultrasound and 1 case of RA diagnosed by MRI confirmed to be normal by postnatal ultrasound).

The prenatal ultrasound gave a similar diagnosis to postnatal ultrasound in 43 cases (14 cases of hydronephrosis, 13 case of PCKD, 9 cases of MCKD, 2 cases of RA, 3 cases of single renal cyst and 2 case of megacystis +hydroureter), while it gave a different diagnosis (false positive) in 9 cases; 4 cases of hydronephrosis diagnosed by prenatal sonography confirmed to be PCKD by postnatal ultrasound, one case of PCKD+one case of MCKD, and one case of megacystis+hydroureter confirmed to be hydronephrosis by postnatal ultrasound, while one case of MCKD diagnosed by prenatal sonography was confirmed to be PCKD by postnatal ultrasound and one case of RA diagnosed by prenatal ultrasound was confirmed to be normal by postnatal ultrasound.

Conclusion: The MRI can be used as a complementary adjunctive modality with excellent tissue contrast, especially in equivocal cases or inconclusive sonographic findings.

(J Turkish-German Gynecol Assoc 2013; 14: 6-10)

Key words: The magnetic resonance imaging (MRI), refining diagnosis, suspected, fetal, renal anomalies

Received: 06 November, 2012
Accepted: 01 January, 2013
Özet

Amaç: Bu prospektif çalışma, tarama sonografisi sırasında saptanan şüpheli fetal renal anomali tanısını aydınlatmada manyetik rezonans görüntüleme (MRG)'nin rolünü saptamak için tasarlandı.

Gereç ve Yöntemler: Rutin ultrason taraması sırasında şüpheli fetal renal anomalisi olan 54 gebe kadın şüpheli renal anomali tanısını aydınlatmak için MRG ile yeniden tarandı. Gebelik sonucu dışarıdan ve postnatal ultrasonografi ile incelendi.

Bulgular: Bu çalışmada 8400 gebe kadının sonografi taraması sırasinda saptanan şüpheli renal anomalisi olan 54 vaka (\%0.6) MRG ile yeniden tarandl.

MRG 46 olguda postnatal ultrason ile benzer tanı verirken (16 olguda hidronefroz, 14 olguda Polikistik Böbrek Hastalığı (PKBH), 9 olguda Multikistik Böbrek Hastalığı (MKBH), 2 olguda Renal Agenezi (RA), 3 olguda tek renal kist ve 2 olguda megakist+hidroüreter) 6 olguda farklı bir tanı (yalancı pozitif) verdi (4 olguda MRG ile teşhis edilen hidronefroz tanısının postnatal ultrason ile PKBH olduğu doğrulandı, ayrıca 1 olguda MRG ile teşhis edilen MKBH tanısının postnatal ultrason ile hidronefroz olduğu doğrulandı ve 1 olguda MRG ile teşhis edilen RA tanısının postnatal ultrason ile normal olduğu doğrulandı). Prenatal ultrason 43 olguda postnatal ultrasona benzer tanılar verirken (14 olguda hidronefroz, 13 olguda PKBH, 9 olguda MKBH, 2 olguda RA, 3 olguda tek renal kist ve 2 olguda megakist+hidroüreter) 9 olguda farklı tanılar (yalancı pozitif) verdi; 4 olguda prenatal ultrason ile teşhis edilen hidronefroz tanısının postnatal ultrason ile PKBH olduğu doğrulandı, PKBH olan 1 olgu+MKBH olan 1 olgu+megakist +hidroüreter olan 1 olgunun postnatal ultrason ile hidronefroz olduğu doğrulandı, 1 olguda prenatal ultrason ile teşhis edilen MKBH tanısının postnatal ultrason ile PKBH olduğu doğrulandı ve 1 olguda prenatal ultrason ile teşhis edilen RA tanısının postnatal ultrason ile normal olduğu doğruland..

Sonuç: Özellikle belirsiz olgularda veya sonografik bulguları kesin olmayanlarda mükemmel doku kontrastı ile MRG tamamlayıcı bir ek yöntem olarak kullanılabilir.

(J Turkish-German Gynecol Assoc 2013; 14: 6-10)

Anahtar kelimeler: Manyetik rezonans görüntüleme (MRG), tanının aydınlatılması, şüpheli, fetal, renal anomaliler

Geliş Tarihi: 06 Kasım 2012

Kabul Tarihi: 01 Ocak 2013 


\section{Introduction}

Ultrasound is the primary imaging method of fetal anomalies. When fetal renal anomalies are identified by prenatal ultrasound, other additional structural abnormalities should be excluded and when isolated renal anomaly is identified, the renal tract architecture and liquor volume should be monitored $(1,2)$.

Oligohydramnios is commonly associated with fetal urinary tract anomalies (3), however, oligohydramnios and maternal obesity or both may limit the diagnostic accuracy of ultrasound $(1,2)$.

Only $40-50 \%$ of cases of fetal malformations are detected prenatally by screening sonography (4). Therefore, the use of magnetic resonance imaging (MRI) is currently accepted as a valuable adjunctive technique for fetal imaging $(5,6)$. Fetal MRI was introduced in 1983, but the ultra-fast MRI sequences allows excellent detection of fetal anatomy without the need for maternal sedation (7-9). MRI as a complementary modality is more popular in such a setting because it enables the fetus to be viewed in multiple planes, irrespective of fetal lie and has excellent resolution $(10,11)$. This study was designed to detect the role of magnetic resonance imaging in refining the diagnosis of suspected fetal renal anomalies detected during screening sonography.

\section{Material and Methods}

Fifty-four pregnant women with suspected fetal renal anomalies, detected during screening ultrasound and more than 14 weeks gestation, were included in this study after informed consent of the patient and approval of the study by the institute ethics committee were obtained. A detailed history was taken from each patient regarding; the gestational age, exposure to possible teratogens and infections. Results of ultrasound or investigations carried out during this pregnancy, history of diabetes and past or family history of congenital fetal anomalies were also recorded. Patients with suspected fetal renal anomalies detected during screening ultrasound were rescanned by MRI to refine the diagnosis of suspected renal anomalies.
Amniocentesis and chromosomal studies were performed for all cases with definite fetal renal anomalies.

Ultrasound examinations were made using Philips HD9 with trans-abdominal probe $2-5 \mathrm{MHz}$ and data were stored in digital form on an external hard disk for rendering and re-analyzing. MRI was carried out using a Philips Interna 1.5 Tesla superconducting magnetic resonance system with a $30 \mathrm{mT} / \mathrm{min}$ gradient for fetal kidney imaging. Axial, coronal and sagittal T2-weighted images were obtained.

The complete MRI procedure was explained to the pregnant women, no sedation was used. Written informed consent was obtained from each case before MRI. The patients were positioned in the supine or left lateral position (9-10).

The assessment was focused on the type of renal anomalies, presence of the anomalies on one side or both sides; presence of other associated fetal anomalies and the amniotic fluid volume. MRI was interpreted by a professor of Radiology who was blinded to ultrasound findings. The MRI findings were compared to ultrasound findings and a professor of Obstetrics \& Gynecology determined the impact of the information added by MRI on the obstetric management. The pregnancy outcome was examined externally and by postnatal ultrasonography which was interpreted by the professor of Radiology. Data were collected, and then analyzed using SPSS Statistical package version 15 , to detect the role of MRI in refining the diagnosis of suspected fetal renal anomalies detected during screening sonography.

\section{Results}

Fifty-four cases of suspected renal anomalies, detected during screening sonography of 8400 pregnant women $(0.6 \%)$ over two years, were rescanned by MRI to refine the diagnosis of suspected renal anomalies in this study. Forty-six (85.2\%) cases of the antenatally diagnosed renal anomalies were unilateral and $8(14.8 \%)$ cases were bilateral. The amniotic fluid volume was normal in 33 (61\%) cases and decreased in 21 (39\%) cases, Table 1.

Two extra-renal anomalies were detected in the studied cases; Arnold-Chiari malformation and congenital talipes equinovar-

Table 1. The fetal renal anomalies diagnosed by MRI

\begin{tabular}{|c|c|c|c|c|c|c|}
\hline \multirow[t]{2}{*}{ Renal anomalies } & \multirow[t]{2}{*}{ Number (\%) } & \multicolumn{2}{|c|}{ Unilateral or bilateral anomalies } & \multicolumn{3}{|c|}{ Amniotic fluid volume } \\
\hline & & $\begin{array}{c}\text { Unilateral } \\
\mathrm{N}=46(85.2 \%)\end{array}$ & $\begin{array}{c}\text { Bilateral } \\
\mathrm{N}=8(14.8 \%)\end{array}$ & $\begin{array}{c}\text { Normal } \\
\mathrm{N}=33(61 \%)\end{array}$ & $\begin{array}{c}\text { Oligohydramnios } \\
\mathrm{N}=21(39 \%)\end{array}$ & $\begin{array}{c}\text { Polyhydramnios } \\
\mathrm{N}=0(0 \%)\end{array}$ \\
\hline Hydronephrosis & $20(37)$ & 18 & 2 & 18 & 2 & 0 \\
\hline PCKD & $14(25.9)$ & 14 & 0 & 0 & 14 & 0 \\
\hline MCKD & $10(18.5)$ & 8 & 2 & 9 & $1 *$ & 0 \\
\hline RA & $5(9.3)$ & 3 & $2 * *$ & 3 & $2 * * *$ & 0 \\
\hline Single renal cyst & $3(5.6)$ & 3 & 0 & 3 & 0 & 0 \\
\hline $\begin{array}{l}\text { Megacystis } \\
+ \text { hydroureter }\end{array}$ & $2(3.7)$ & 0 & 2 & 0 & 2 & 0 \\
\hline
\end{tabular}


Table 2. Comparison between MRI and postnatal ultrasound findings

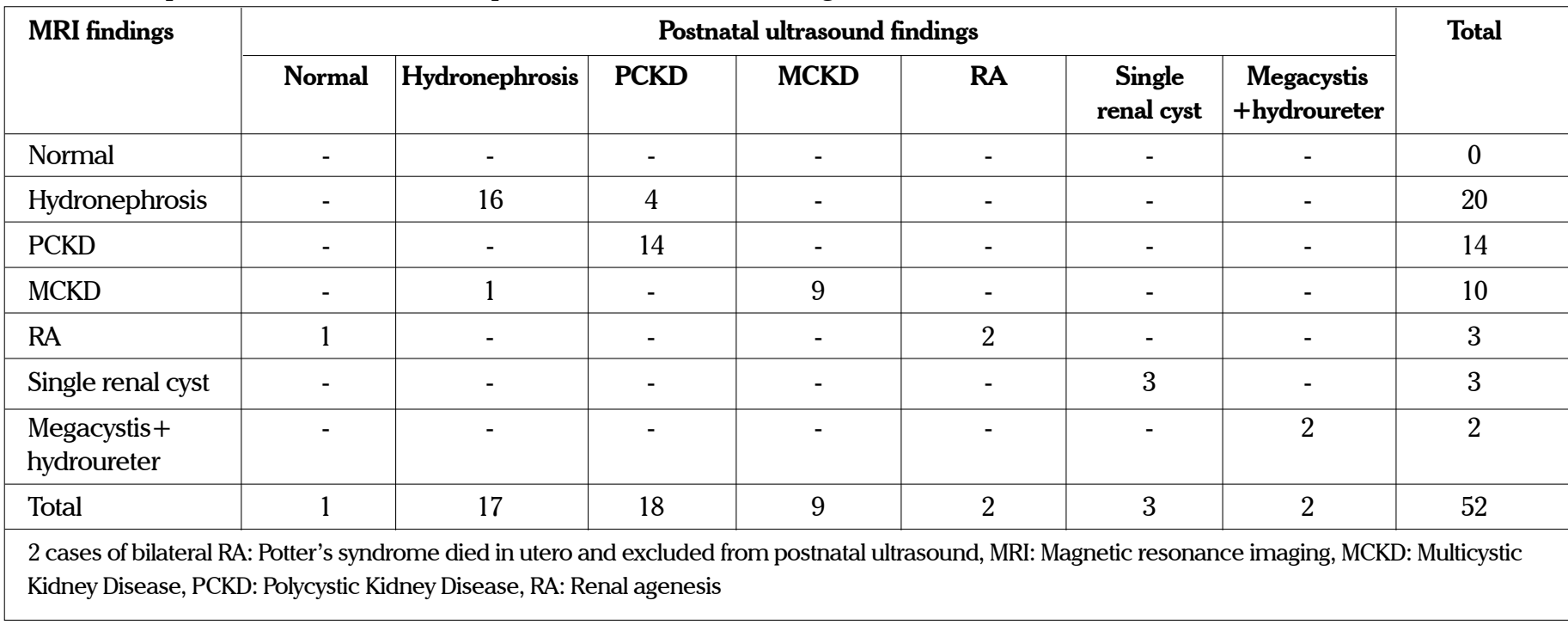

Table 3. Comparison between prenatal ultrasound and postnatal ultrasound findings

\begin{tabular}{|l|c|c|c|c|c|c|c|c|}
\hline \multirow{2}{*}{$\begin{array}{l}\text { Prenatal } \\
\text { ultrasound } \\
\text { findings }\end{array}$} & Normal & Hydronephrosis & PCKD & MCKD & RA & $\begin{array}{c}\text { Single } \\
\text { renal cyst }\end{array}$ & $\begin{array}{c}\text { Megacystis } \\
\text { +hydroureter }\end{array}$ \\
\hline Normal & - & - & - & - & - & - & - & 0 \\
\hline Hydronephrosis & - & 14 & 4 & - & - & - & - & 18 \\
\hline PCKD & - & 1 & 13 & - & - & - & - & 14 \\
\hline MCKD & - & 1 & 1 & 9 & - & - & - & 11 \\
\hline RA & 1 & - & - & - & 2 & - & - & 3 \\
\hline Single renal cyst & - & - & - & - & - & 3 & - & 3 \\
\hline $\begin{array}{l}\text { Megacystis } \\
+ \text { hydroureter }\end{array}$ & - & 1 & - & - & - & - & 2 & 3 \\
\hline Total & 1 & 17 & 18 & 9 & 2 & 3 & 2 & 52 \\
\hline $\begin{array}{l}2 \\
\text { Kidney Disease, RA: Renal agenesis }\end{array}$
\end{tabular}

us, were both detected with bilateral hydronephrosis. Two cases of chromosomal aberration (3.7\%) were detected in the studied cases. During antenatal follow up of the prenatal diagnosed cases with renal anomalies, one case of mild hydronephrosis due to Pelvi-Uretric Junction (PUJ) obstruction (renal pelvic diameter $(\mathrm{RPD})<10 \mathrm{~mm}$ ) had progressed to the severe form (RPD $>15 \mathrm{~mm}$ ) and 2 cases of bilateral RA (Potter's syndrome died in utero $=$ Intra-uterine Fetal Death (IUFD)). Out of 52 live births 1 neonatal death occurred due to bilateral MCKD with trisomy 18 (Edwards syndrome), Table 1.

When the MRI findings were compared with postnatal ultrasound findings, it provided the same diagnosis in 46 cases, while it gave different diagnosis (false positive) in 6 cases (Table 2), and when the prenatal ultrasound was compared with postnatal ultrasound findings, gave the same diagnosis in 43 cases, while it gave a different diagnosis (false positive) in 9 cases (Table 3).
The MRI was $100 \%$ sensitive, $99.9 \%$ specific with $89.5 \%$ Positive Predictive Value (PPV) and accuracy in the diagnosis of suspected renal anomalies, while prenatal ultrasound was $100 \%$ sensitive, $99.9 \%$ specific with $85 \%$ PPV and accuracy (Table 4).

\section{Discussion}

Oligohydramnios is commonly associated with fetal urinary tract anomalies and the efficacy of ultrasound as a primary imaging tool in the diagnosis of fetal anomalies is decreased in the presence of oligohydramnios (12-15). Fifty-four (0.6\%) cases of suspected renal anomalies, detected during screening sonography of 8400 pregnant women $(0.6 \%)$ over two years, were rescanned by MRI to refine the diagnosis of suspected renal anomalies in this study. Literature reports that the frequency of congenital anomalies of the kidney and urinary tract (CAKUT), which can be detected sonographically in unselected 
Table 4. The accuracy of the MRI and prenatal ultrasound in diagnosing fetal renal anomalies

\begin{tabular}{|l|c|c|}
\hline Parameter & MRI & $\begin{array}{c}\text { Prenatal } \\
\text { ultrasound }\end{array}$ \\
\hline Accuracy* & $89.5 \%$ & $85 \%$ \\
\hline Sensitivity** & $100 \%$ & $100 \%$ \\
\hline Specificity*** & $99.9 \%$ & $99.9 \%$ \\
\hline PPV (Positive predictive value) & $89.5 \%$ & $85 \%$ \\
\hline NPV (Negative predictive value) & $100 \%$ & $100 \%$ \\
\hline $\begin{array}{l}\text { MRI: Magnetic resonance imaging, * True positive+true negative / } \\
\text { True positive+ true negative+false positive+false negative X 100, ** }\end{array}$ \\
$\begin{array}{l}\text { True positive / True positive+False negative X 100, *** True negative } \\
\text { / True negative+False positive X 100, PPV (Positive predictive value): } \\
\text { True positive / True positive+False positive X 100, NPV (Negative pre- } \\
\text { dictive value): True negative / True negative+False negative X 100 }\end{array}$ \\
\hline
\end{tabular}

populations, is about 0.1 to $0.7 \%$ (16) and the incidence of renal abnormalities detected by prenatal screening is $0.65 \%$ (17).

The MRI diagnosed 29 (53.7\%) cases of parenchymal renal disease, 20 (37\%) cases of hydronephrosis (Figure 1) due to PUJ obstruction, 3 (5.6\%) cases of single renal cyst (Figure 2) and $2(3.7 \%)$ cases of megacystis +hydroureter (Figure 3 ) due to a posterior urethral valve (PUV).

Twenty-seven fetuses with suspected renal anomalies on ultrasound (study group) were rescanned by MRI by Gupta et al. (10) and they found that a total of $10(37 \%)$ cases were associated with severe oligohydramnios (10). It was reported that unilateral hydronephrosis is the most common fetal renal anomaly and normal amniotic fluid volume is the usual finding, but oligohydramnios is associated with bilateral renal anomalies $(18,19)$. Also, it was reported that the presence of a normal amount of amniotic fluid does not eliminate the possibility of a urinary tract abnormality nor guarantee normal renal function after birth $(20,21)$.

Two extra-renal anomalies were detected in the studied cases; Arnold-Chiari malformation and congenital talipes equinovarus and both were detected with bilateral hydronephrosis. Two cases of chromosomal aberration (3.7\%) were detected in the studied cases; one case of numerical abnormality or trisomy 18 with bilateral MCKD and one case of structural abnormality or Cri du chat syndrome. Most of the fetal renal anomalies are isolated anomalies but the prognosis may be altered considerably by the detection of other anomalies which could indicate a genetic disorder or syndrome (22). Bilateral renal agenesis should be suspected when severe oligohydramnios is noted and with bilateral RA there is an increased incidence of chromosomal abnormalities, or multiple malformation syndromes such as VATER (vertebrae, anus, trachea, esophagus and renal) association or Potter's syndrome, the prognosis is uniformly lethal and the option of pregnancy termination should be offered (21).

During antenatal follow up of the prenatal diagnosed cases with renal anomalies, 2 cases of bilateral RA (Potter's syndrome) died in utero $=$ IUFD. Out of 52 live births 1 neonatal death occurred due to bilateral MCKD with trisomy 18 (Edwards's syndrome). The most common type of fetal cystic kidney disease is MCDK (Potter type II), which is usually unilateral with normal amniotic fluid and good prognosis, but when bilateral MCKD is diagnosed, it is usu-

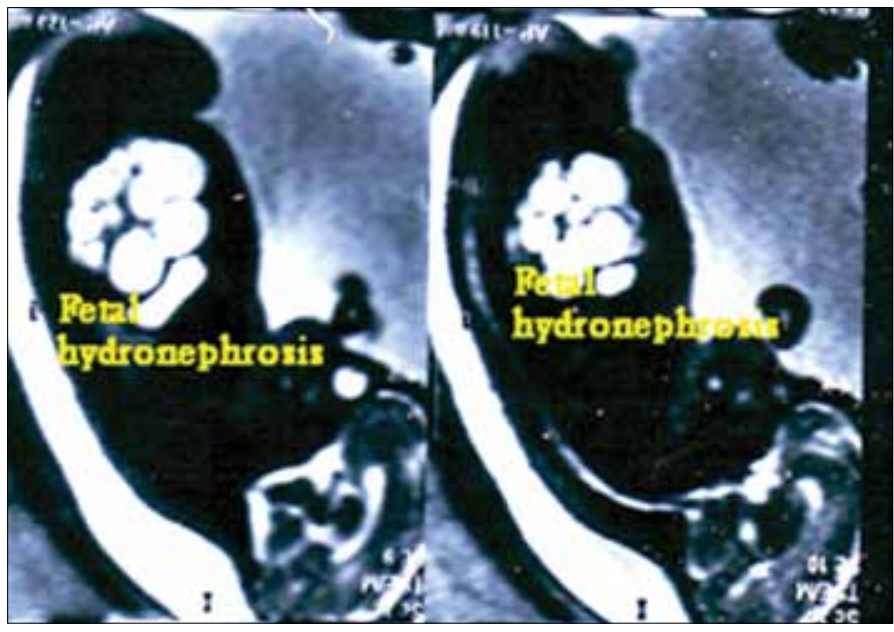

Figure 1. Fetal MRI shows fetal hydronephrosis

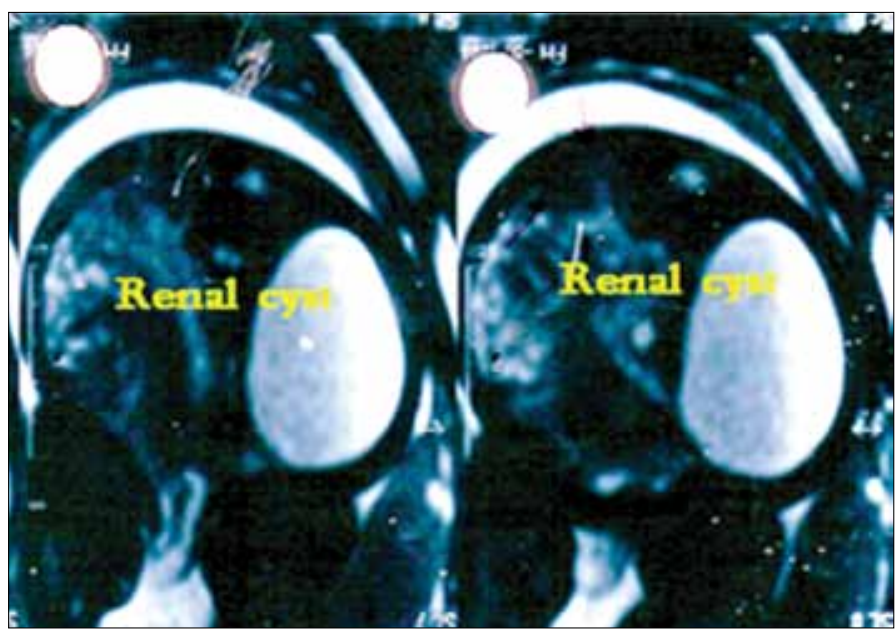

Figure 2. Fetal MRI shows single renal cyst

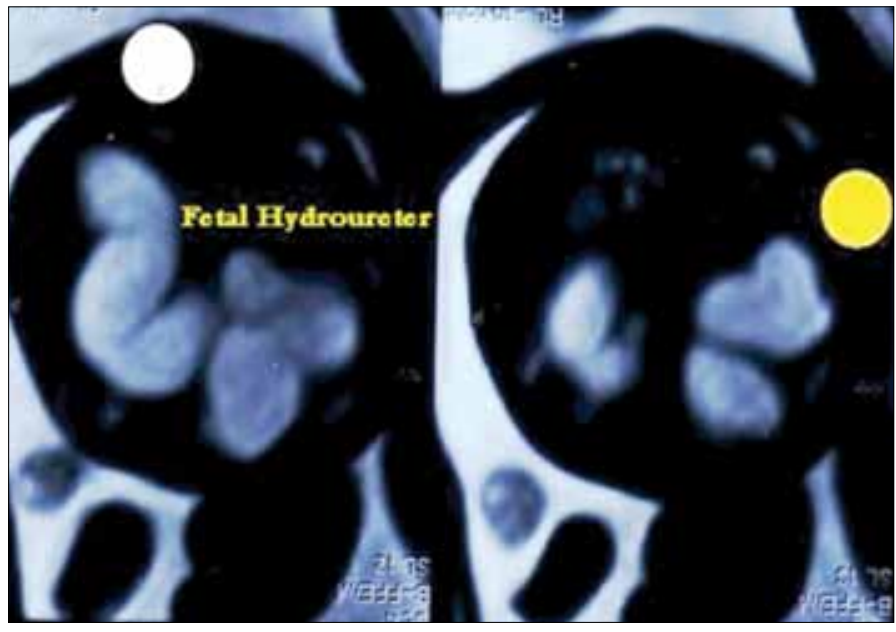

Figure 3. Fetal MRI shows fetal hydroureter

ally accompanied by oligohydramnios and the prognosis is very poor, because of pulmonary hypoplasia (21).

When the MRI findings were compared with postnatal ultrasound finding, it provided the same diagnosis in 46 cases, while it gave a different diagnosis (false positive) in 6 cases, and when 
the prenatal ultrasound was compared with postnatal ultrasound findings; the same diagnosis was given in 43 cases, while it gave a different diagnosis (false positive) in 9 cases.

The MRI was $100 \%$ sensitive, $99.9 \%$ specific with $89.5 \%$ PPV and accuracy in the diagnosis of suspected renal anomalies; and gave a similar diagnosis to postnatal ultrasound in 46 cases, while it gave a different diagnosis (false positive) in 6 cases.

Using the postnatal findings as the gold standard of assessment and diagnosis; the suspected renal anomalies during prenatal screening were confirmed by MRI in 16 cases out of $18(90 \%$ sensitivity) in the Ibrahim et al study and in 19 cases out of 27 in the Gupta et al. (10) study (70.4\% accuracy) (3).

Twenty-six fetuses with sonographically suspected congenital anomalies (CNS, abdominal, musculoskeletal, renal and Meckel Gruber syndrome) were rescanned by MRI to evaluate the contribution of adding MRI findings to sonographic data when assessing fetal anomalies and to determine how this addition may affect the management of pregnancy by Behairy et al. They concluded that the MRI can be used as a complementary modality to ultrasound in diagnosing fetal abnormality in which ultrasound findings are inconclusive or equivocal (23).

The prenatal ultrasound was 100\% sensitive, $99.9 \%$ specific with $85 \%$ PPV and accuracy in the diagnosis of suspected renal anomalies; it gave similar diagnosis to postnatal ultrasound in 43 cases, while it gave a different diagnosis (false positive) in 9 cases. Abdelazim et al. (3) concluded that the prenatal ultrasound failed to detect 6 cases out of 18 fetal renal anomalies (72\% sensitivity), also they concluded that the hydronephrosis can be misdiagnosed by prenatal ultrasound as MCKD or PCKD.

Seventy-six (76) cases of Intrauterine Growth Retardation (IUGR) with oligohydramnios and sixteen cases out of 27 of structural defects represented bilateral renal agenesis were detected by Reuss et al. (24), 11 of them were diagnosed by prenatal ultrasound scanning (sensitivity of 76\%). Shlossman et al. (21) reported that the MCKD can easily be diagnosed in utero by antenatal ultrasound with a $100 \%$ detection or accuracy rate. In this study, the MRI was more accurate (89.5\%) than the prenatal sonography (85\%) in diagnosing fetal renal anomalies,. It can be used as a complementary adjunctive modality with excellent tissue contrast especially in equivocal cases or inconclusive sonographic findings.

Although the MRI was more accurate than the prenatal sonography in diagnosing fetal renal anomalies in this study, it did not change the perinatal management of the studied cases.

Oligohydramnios is commonly associated with fetal urinary tract anomalies, however, oligohydramnios and maternal obesity or both may limit the diagnostic accuracy of the prenatal ultrasound.

\section{Conflict of interest}

No conflict of interest was declared by the authors.

\section{References}

1. Callen PW. Amniotic fluid: its role in fetal health and disease. In: Callen PW (ed), Ultrasonography in Obstetrics and Gynecology (ed4), Philadelphia, WB, Saunders 2000a; 517-50.

2. Callen PW. Amniotic fluid: its role in fetal health and disease. In:
Callen PW (ed), Ultrasonography in Obstetrics and Gynecology (ed4), Philadelphia, WB, Saunders 2000b; 638-59.

3. Abdelazim IA, Abdelrazak KM, Ramy AR, Mounib AM. Complementary roles of prenatal sonography and magnetic resonance imaging in diagnosis of fetal renal anomalies. Aust N Z J Obstet Gynaecol 2010; 50: 237-41. [CrossRef]

4. Xu HX, Zhang QP, Lu MD, Xiao XT. Comparison of two-dimensional and three-dimensional sonography in evaluating fetal malformations. J Clin Ultrasound 2002; 30: 515-25. [CrossRef]

5. Chen Q, Levine D. Fast fetal magnetic resonance imaging techniques. Top Magn Reson Imaging 2001; 12: 67-79. [CrossRef]

6. Kubik-Huch RA, Huisman TA, Wisser J, Gottstein-Aalame N, Debatin $\mathrm{JF}$, Seifert B, et al. Ultrafast MR imaging of the fetus. AJR Am J Roentgenol 2000; 174: 1599-606. [CrossRef]

7. Breysem L, Bosmans H, Dymarkowski S, Schoubroeck DV, Witters I, Deprest J, et al. The value of fast MR imaging as an adjunct to ultrasound in prenatal diagnosis. Eur Radiol 2003; 13: 1538-48. [CrossRef]

8. Wagenvoort AM, Bekker MN, Go AT, Vandenbussche FP, van Buchem MA, Valk J, van Vugt JM. Ultrafast scan magnetic resonance in prenatal diagnosis. Fetal Diagn Ther 2000; 15: 364-72. [CrossRef]

9. Cassart M, Massez A, Metens T, Rypens F, Lambot MA, Hall M, et al. Complementary role of MRI after sonography in assessing bilateral urinary tract anomalies in the fetus. AJR Am J Roentgenol 2004; 182: 689-95. [CrossRef]

10. Gupta P, Kumar S, Sharma R, Gadodia A, Roy KK, Sharma JB. The role of magnetic resonance imaging in fetal renal anomalies. Int $\mathrm{J}$ Gynaecol Obstet 2010; 111: 209-12. [CrossRef]

11. Hosny IA, Elghawabi HS. Ultrafast MRI of the fetus: an increasingly important tool in prenatal diagnosis of congenital anomalies. Magn Reson Imaging 2010; 28: 1431-9. [CrossRef]

12. Keith L. Moore, T. V. N. Persaud. The developing human clinically oriented embryology. In: Moore et al, 2003: (The Developing Human Clinically Oriented Embryology). 7th edition. Philadelphia, PA, Saunders 2003; 12: 210-45.

13. Narlawar RS, Hanchate V, Raut A, Hira P, Nagar A, Chaubal NG. Renal agenesis and seminal vesicle cyst. J Ultrasound Med 2003; 22: 225-8.

14. Sherer DM, Langer O. Oligohydramnios: use and misuse in clinical management. Ultrasound Obstet Gynecol 2001; 18: 411-9. [CrossRef]

15. Sepulveda W, Campana C, Carstens E, Rodriguez J. Prenatal sonographic diagnosis of bilateral ureteroceles: the pseudoseptated fetal bladder. J Ultrasound Med 2003; 22: 841-4.

16. Dugoff L. Ultrasound diagnosis of structural abnormalities in the first trimester. Prenat Diagn 2002; 22: 316-20. [CrossRef]

17. Livera LN, Brookfield DS, Egginton JA, Hawnaur JM. Antenatal ultrasonography to detect fetal renal abnormalities: a prospective screening programme. BMJ 1989; 298: 1421-3. [CrossRef]

18. Stamilio DM, Morgan MA. Diagnosis of fetal renal anomalies. Obstetrics and Gynecology Clinics 1998; 25: 527-52. [CrossRef]

19. Dillon E, Rayall A. A 10 year audit of antenatal ultrasound detection of renal disease. Br J Radiol 1998; 71: 497-500.

20. Cohen HL, Kravets F, Zucconi W, Ratani R, Shah S, Dougherty D. Congenital abnormalities of the genitourinary system. Semin Roentgenol 2004; 39: 282-303. [CrossRef]

21. Philip Shlossman. Prenatal diagnosis of urinary tract abnormalities. In: Gonzalez, Ricardo and Ludwikowski, Barbara M 2011: (Handbook of Urological Diseases in Children). New Jersey; Singapore: World Scientific, 2011 publishing Co. Pte. Ltd. 2011; Chapter 1: 3-33.

22. Wellesley D, Howe DT. Fetal renal anomalies and genetic syndromes. Prenat Diagn 2001; 21: 992-1003. [CrossRef]

23. Behairy NH, Talaat S, Saleem SN, El-Raouf MA. Magnetic resonance imaging in fetal anomalies: What does it add to 3D and 4D US? Eur J Radiol 2010; 74: 250-5. [CrossRef]

24. Reuss A, Wladimiroff JW, vd Wijngaard JA, Pijpers L, Stewart PA. Fetal renal anomalies, a diagnostic dilemma in the presence of intrauterine growth retardation and oligohydramnios. Ultrasound Med Biol 1987; 13: 619-24. [CrossRef] 